\title{
6.4 Діяльність банків України на сучасному етапі
}

Функціональний банківський сектор в Україні $є$ необхідною умовою створення ефективної ринкової економіки та сприяє завоюванню міцних позицій на світовому ринку. Для належного функціонування банківської системи в Україні розроблено нормативну базу, впроваджені принципи діяльності банків, методи та інструменти грошово-кредитної політики тощо. Однак швидкий розвиток фінансових глобалізаційних процесів ставить перед банківською системою щоразу більше завдань. За останні роки в умовах серйозних економічних та політичних кризових явищ в Україні питання щодо нинішнього стану розвитку банківської системи є вкрай актуальними.

Напрямам удосконалення функціонування банківської системи присвячено наукові праці В. Ворочек, М. Звєрякова, Е. Карлетті, В. Кротюк, О. Марианні, В. Міщенка, С. Міщенко, С. Науменкової, В. Шпачука, про те в сучасних умовах дана тематика потребує постійного дослідження та удосконалення.

Комерційні банки на сучасному етапі $є$ найважливішою ланкою ринкової економіки. У процесі їх діяльності відбувається залучення і накопичення вільних грошей, що приносять дохід своїм власникам i одночасно $\epsilon$ джерелом формування ресурсів банків. При цьому комерційні банки забезпечують посередництво в кредитуванні через перерозподіл тимчасово вільних грошових коштів підприємств, організацій, населення, держави на умовах повернення грошового капіталу зі сфер накопичення у сфери використання. Завдяки комерційним банкам діє механізм перерозподілу капіталу за сферами і галузями виробництва. Таким чином банки мобілізують капітали, що $є$ необхідними для розвитку економіки, а саме: розширення виробництва, інвестування, запровадження інновацій та інше. Вагомим в банківській діяльності $\epsilon$ посередництво при розрахунках, що сприяло розвитку електронних безготівкових платежів і появи найрізноманітніших форм розрахунків, зокрема платіжних карток, чеків тощо. 
Протягом останніх років розпочався активний процес інтеграції банківської системи України у світову фінансову систему на основі іiі адаптації до міжнародних вимог функціонування та регулювання банківських систем. Тому в нинішніх умовах стратегічним завданням Національного банку України $\epsilon$ розбудова стійкої, ефективної, конкурентоспроможної банківської системи, яка б сприяла довгостроковому економічному зростанню країни, іiі фінансовій безпеці, що можливо через забезпечення стійкості банківської системи, іiі прозорості та високого рівня конкурентоспроможності [273].

Банківська сфера $є$ однією $з$ провідних ланок фінансової системи, від стабільності якої залежить подальший розвиток економіки України, можливість виходу на міжнародні ринки та активної участі у глобалізаційних процесах. Останніми роками відбулися значні зміни щодо напрямів реформування банківської системи спрямовани на ії оздоровлення та розвиток. Програма реформ оздоровлення банківської системи [282], запропонована Національним банком України, призвела до суттєвого зменшення кількості банківських установі та до радикальних змін у функціонуванні системних банків.

Станом на 1 січня 2021 р. ліцензію Національного банку України отримали 74 банківських установ (зокрема 33 банки з іноземним капіталом, з них 23 з 100\% іноземним капіталом). 3 початку 2014 р. кількість функціонуючих банківських установ скоротилася на 106 (зокрема на 13 банків з іноземним капіталом). Кількість банків з 100\% іноземним капіталом збільшилась на 4. Як бачимо, в Україні спостерігається тенденція до скорочення кількості банківських установ вітчизняних власників, причому, банки 3 100\% іноземним капіталом мають тенденцію до підвищення кількості. (Таб. 6.4.1).

Чинниками, що показали накопичені проблеми банківської системи України останніми роками були економічна та політична кризи. При цьому деякі банки відмовлялися повертити кошти своїм вкладникам, інші-були не в змозі виконувати нормативи та вимоги Національного банку, а також розраховуватись за кредитами рефінансування. Декілька банків опинились на захопленій 
зовнішнім агресором території. Тому очищення банківської системи від проблемних банків було неминучим.[280]

Зростання частки іноземного банківського капіталу сприяє залученню іноземних інвестицій в країну, збільшенню обсягів кредитування населення, росту рівня рентабельності банків, підвищенню гарантування вкладів, Підвищенню якості системи управління банківськими ризиками; зростання обсягу банківських ресурсів і посилення стабільності їхніх джерел; розширення спектру банківських продуктів, комплексний підхід до обслуговування різних клієнтів; запровадження міжнародного досвіду фінансового оздоровлення, може принести в країну новітні банківські технології та фінансові продукти.

До основних негативних наслідків функціонування іноземних банків в Україні можна віднести те, що їхня присутність може послабити позиції ще недостатньо розвиненої банківської системи нашої країни. [286]

Однак в загальній кількості діючих банків в Україні спостерігається збільшення питомої ваги банків з участю держави в капіталі («Приватбанк», «Ощадбанк», «Укрексімбанк», «Укргазбанк»). Відповідні банки витримали вимоги НБУ щодо капіталізації та втримали конкурентні позиції виконуючи вимоги регулятора.

Таблиця 6.4.1.

Кількість комерційних банків в Україні з 2008 по 2020 рр.

\begin{tabular}{|c|c|c|c|}
\hline Рік & $\begin{array}{c}\text { Кількість діючих } \\
\text { банків }\end{array}$ & $\begin{array}{c}\text { 3 них з іноземним } \\
\text { капіталом }\end{array}$ & $\begin{array}{c}\text { У т. із 100\% іноземним } \\
\text { капіталом }\end{array}$ \\
\hline 01.01 .2011 & 176 & 55 & 20 \\
\hline 01.01 .2012 & 176 & 53 & 22 \\
\hline 01.01 .2013 & 176 & 53 & 22 \\
\hline 01.01 .2014 & 180 & 49 & 19 \\
\hline 01.01 .2015 & 163 & 51 & 17 \\
\hline 01.01 .2016 & 117 & 41 & 17 \\
\hline 01.01 .2017 & 96 & 38 & 18 \\
\hline 01.01 .2018 & 82 & 38 & 23 \\
\hline 01.01 .2019 & 77 & 37 & 23 \\
\hline 01.01 .2020 & 75 & 35 & 33 \\
\hline 01.01 .2021 & 74 & & \\
\hline
\end{tabular}

*3а даними [281]

Основиними причинами ліквідації банків був: незадовільний фінансовий стан та невиконання нормативів, виявлення незаконних дій після фінмоніторингів, непрозора структура власності, добровільний вихід з ринку. 
Та найбільшою проблемою була неплатоспроможність багатьох банків, тому у 2014 р. особливо гостро постало питання обов'язкового збільшення статутних капіталів (докапіталізації) банківських установ. Цей захід було спрямовано на зміцнення стійкості українських банків до різноманітних негативних впливів і ризиків, забезпечення їхньої здатності виконувати свою основну функцію фінансових посередників у процесі розвитку національної економіки.

Результатом очищення банківської системи повинне стати ефективне функціонування механізму реалізації монетарної політики Національним банком України; впевненість вкладників у вчасному та повному обсязі їхніх коштів; спрямування залучених банками коштів на кредитування бізнесу, зокрема малого та середнього, а не на фінансову підтримку компаній, що належали акціонерам банку; зниження вартості кредитів; збільшення обсягів кредитних ресурсів доступних для підприємств; підвищення стійкості банків до макроекономічних шоків підвищилася, банки матимуть достатній запас ліквідності та капіталу, щоб стабільно працювати навіть в умовах рецесії.[280]

Відповідно до цпередбачені такі групи банків:

-банки 3 державною часткою - банки, в яких держава прямо чи опосередковано володіє часткою понад 75\% статутного капіталу банку;

- банки іноземних банківських груп - банки, контрольні пакети акцій яких належать іноземним банкам або іноземним фінансово-банківським групам;

- банки $з$ приватним капіталом - банки, в яких серед кінцевих власників істотної участі $є$ один чи кілька приватних інвесторів, що прямо та/або опосередковано володіють не менше ніж 50\% статутного капіталу банку.[283]

Ліквідація проблемних банків, з одного боку, позитивно впливає на прозорість банківської системи, але разом з тим різке скорочення кількості банків, може призвести до погіршення конкурентного середовища на ринку банківских послуг та умов надання банківських продуктів, що може нести негативні наслідки для розвитку економіки в цілому. 
Слід зазначити, що для кожної країни необхідним є така кількість банківських установ котра збільшила б проникнення фінансових послуг, враховувала б реальні проблеми суб'єктів господарювання залежно від специфіки їх діяльності. Тому першочерговим завданням держави $\epsilon$ забезпечення належної банківської конкуренції, а не скорочення кількості банків. Відповідно до даних Свропейської банківської федерації на кінець 2017 року в Австрії функціонувало 572 банки, в Іспанії-206, у Франції - 422, в Італії 546, в Німеччині - 1632 установи. [293]

Аналіз сучасного стану банківської системи України дозволяє визначити найбільш гострі проблеми сучасної банківської системи до яких слід віднести негативний вплив політичних процесів, недовіра до банків, девальвація національної грошової одиниці, низький рівень ризик менеджменту банків, суперечливість механізму рефінансування українських банків; невисока якість кредитного портфеля банків тощо.

Девальвація національної грошової одиниці значно вплинула на вітчизняну банківську систему. Протягом 2014-2017 років гривня девальвувало по відношення до долара США більше ніж у три рази, що спричинило зростанню проблемної заборгованості клієнтів банків та валютних активів і зобов’язань

Основні показники банківської діяльності за останні 6 років зображено в таблиці 6.4.2.

Таблиця 6.4.2.

Основні показники банківської діяльності в Україні (млн.грн).

\begin{tabular}{|c|c|c|c|c|c|c|}
\hline Показники & 01.01 .2016 & 01.01.2017 & 01.01.2018 & 01.01.2019 & 01.01 .2020 & 01.01 .2021 \\
\hline 1. Активи банків & 1254385 & 1256299 & 1336358 & 1360764 & 1494460 & 1822814 \\
\hline 1.1.Надані кредити & 1009768 & 1005923 & 1042798 & 1118618 & 1033539 & 963664 \\
\hline $\begin{array}{lcc}\text { У } & \text { т.ч. } & \text { кредити } \\
\text { субєктам господарі }\end{array}$ & 830632 & 847092 & 870302 & 919054 & 822020 & 752503 \\
\hline $\begin{array}{lrl}\text { У } & \text { т.ч. } \\
\text { особедам } & & \\
\end{array}$ & 175711 & 157385 & 170938 & 196634 & 206761 & 199556 \\
\hline $\begin{array}{ll}\text { 2. } & \text { Зобовязання банків } \\
& \text { (млн. грн) }\end{array}$ & 1150672 & 1132515 & 1172761 & 1205114 & 1293606 & 1612474 \\
\hline $\begin{array}{lcc}\text { У } & \text { т.ч. } \quad \text { кошти } \\
\text { господарювання } & \end{array}$ & 318568 & 369913 & 403927 & 406166 & 498156 & 646491 \\
\hline У т.ч. кошти фізичних огсіб & 402137 & 437152 & 478656 & 508869 & 552592 & 682029 \\
\hline
\end{tabular}

*3а даними [285] 
Слід підкреслити, що незважаючи на зменшення кількості банків та труднощі у їх діяльності, спостерігається збільшення активів банків України, що дозволяє зробити висновок про підвищення їх потужності та стабільності. Найбільшу питому вагу в структурі активів банків посідають кредити.

Банківські кредити господарюючих суб'єктів $є$ домінуючою складовою кредитного портфелю банківської системи України. Питома вага цих кредитів у загальній сумі кредитного портфелю українських банків мала стійку тенденцію до зростання: значення цього показника становило 69\% на кінець 2019p. Але для економіки країни розвиток банківського кредитування суб'єктів господарювання є надто повільним

Основними причинами недостатнього розвитку у сфері кредитування суб'єктів господарювання в Україні є: повільне відновлення економіки після іiі падіння у 2014-2015 рр.; повільне зниження рівня інфляції; незадовільна якість вже сформованого кредитного портфелю; комплекс проблем банківської системи; інструментів безпечного та надійного інвестування вільних ресурсів банків.

Зв'язок між динамікою виробництва у базових галузях економіки та динамікою корпоративного кредитування $\epsilon$ тісним, тому що кредитні ресурси $\epsilon$ джерелом активізації виробництва та економічного зростання держави, але банки уникають кредитування збиткових, недостатньо прозорих та неплатоспроможних підприємств, фінансовий стан яких гальмує надання кредитів банками.

Ситуацію у сфері корпоративного кредитування в Україні ускладнює також значна частка підприємств, що працюють в «тіні», адже процедура надання та супроводження корпоративних кредитів передбачає всебічний аналіз балансових та інших фінансових показників підприємств, перерахунок чергових кредитних траншів на рахунки юридичних осіб у безготівковій формі, що входить у суперечність з особливостями функціонування таких підприємств.[292]

В цілому банківська система України має достатній обсяг ресурсів для кредитування. Значна частина ресурсів банків останніми роками були задіяними 
в міжбанківському кредитуванні, придбанні ОВДП та депозитних сертифікатів НБУ. Ці ресурси при сприятливих умовах могли б працювати як довгострокові кредити субєктів господарювання, однак обираючи між ризиковим кредитуванням корпоративних позичальників та значно безпечнішим кредитуванням дефіциту державного бюджету (ОВДП) чи короткостроковим кредитуванням НБУ (депозитні сертифікати) банки обирають більш надійний для себе шлях кредитування держави. Так станом на 01.01.2021року вкладення банками в цінні папери склали 791345 млн.грн., або 43\% від загальної кількості активів.

Починаючи 3 травня 2017 p. НБУ почав публікувати статистику непрацюючих кредитів (NPL), розрахованих за новими правилами на основі загальноприйнятих у світі стандартів. Частка непрацюючих кредитів (NPL) в Україні становила $41 \%$ на початок 2021 року в той час як на початок 2020 року вона становила $48 \%$, а на початок 2019 року - 53\%

У 2020 році державні банки: за рік списали 30,6 млрд у гривні та 3,1 млрд у доларовому еквіваленті. Це дозволило знизити частку непрацюючих кредитів.. У результаті загальна частка NPL у банківському секторі знизилася за 2020 рік на 7,4 в.п.

На даний час всі непрацюючі кредити визнані банками, рівень покриття їх резервами становить приблизно 98\%. ,Проте все ще велика їх частка є тягарем для банківського сектору, особливо для держбанків, у яких сконцентровано понад 70\% NPL сектору (близько 42\% припадає на Приватбанк).

Висока частка NPL - результат кредитної експансії минулих років, коли стандарти оцінювання платоспроможності позичальників були низькими, а права кредиторів недостатньо захищеними. [291]

За останні роки помітно і зріс попит на кредити серед населення. Утім, у структурі кредитування населення України поки переважають короткострокові позики (.

Банківська система на даному етапі все ще не може бути джерелом дешевих i довгострокових кредитних ресурсів. Саме високі кредитні ставки є вагомою 
перешкодою для отримання довготермінових кредитів і обмежують прагнення бізнесу позичати необхідні йому кошти в українських банках.

Позитивни в діяльності банків є зростання депозитних ресурсів банків

Також населення доволі поступово збільшує терміни зберігання своїх коштів на депозитних рахунках. При цьому в 2020 році ставки за депозитами знизилися майже вдвічі. Якщо на початку року індекс UIRD за депозитами на 12 місяців у гривні становив $15,18 \%$ річних, в доларах $-2,54 \%$, а в євро - 1,09\%, то наприкінці 2020-го - 8,63\%, 1,21\% і 0,56\% відповідно. Збільшення обсягів коштів на депозитних рахунках у вітчизняних банках передбачає зростання довіри бізнесу і населення до української банківської системи.

У загальній структурі депозитів фізичних і юридичних осіб все ще лідируючу позицію займають депозити на вимогу.

Вагомим фактором, який зупиняє клієнтів банків від відкриття строкових депозитів є неможливість скористатися достроково своїми коштами в разі потреби.

Тому банки надають деякі супутні послуги, для залучення сторокових вкладів, наприклад, відкривають кредитну лінію аж до 80\% суми депозиту на доволі вигідних умовах,.тому навіть в разі непередбачених ситуацій вклад продовжує працювати, а клієнт не втрачає прибутковість за попередній період

3 останній рік, під час карантину, спостерігалося загальне зниження бізнесактивності та падіння попиту на кредити й банківські послуги, а також наявність неплатежів за кредитами, що негативно позначається на доходах банків (Таблиця 6.4.3.).

Коронакриза погіршила фінансовий стан банків, однак кількість збиткових банків не зросла. У 2020 році з 73 платоспроможних банків 65 банків були прибутковими.

При зниженні вартості фондування та спаду ділової активності банківський сектор України залишається прибутковим. Однак прибуток банківського сектору дуже концентрований, так,ПриватБанк сформував $61 \%$ усього прибутку (25,3 млрд грн), а п'ять найприбутковіших банків - 89\% прибутку.[279] 
Таблиця 6.4.3.

\section{Доходи і витрати банків України у 2013-2020 рр.,}

Млн грн. *

\begin{tabular}{|c|c|c|c|c|c|}
\hline Показники & 2016* & $\begin{array}{c}2017^{*} \\
\text { (A4) }\end{array}$ & $\begin{array}{r}\text { 2018* } \\
(\mathbf{A 4})\end{array}$ & $\begin{array}{l}2019 \\
\text { (A4) }\end{array}$ & $2020^{*}$ \\
\hline ДОХОДИ & 190691 & 178054 & 204554 & 243102 & 249745 \\
\hline Процентні доходи & 135807 & 124009 & 140803 & 152954 & 147312 \\
\hline Комісійні доходи & 31362 & 37138 & 50969 & 62057 & 70640 \\
\hline $\begin{array}{c}\text { Результат від переоцінки та } \\
\text { від операцій купівлі- } \\
\text { продажу }\end{array}$ & 8243 & 7224 & 1853 & 16225 & 21433 \\
\hline Інші операційні доходи & 9605 & 7264 & 8589 & 8147 & 6940 \\
\hline Інші доходи & 3946 & 1349 & 1809 & 2809 & 2657 \\
\hline $\begin{array}{c}\text { Повернення } \\
\text { списаних активів }\end{array}$ & 1728 & 1070 & 532 & 909 & 763 \\
\hline ВИТРАТИ & 350078 & 204545 & 182215 & 184746 & 208449 \\
\hline Процентні витрати & 91638 & 70971 & 67760 & 74062 & 62888 \\
\hline Комісійні витрати & 7182 & 9650 & 13159 & 18096 & 24111 \\
\hline $\begin{array}{l}\text { Інші операційні } \\
\text { витрати }\end{array}$ & 10920 & 11719 & 16800 & 11790 & 16049 \\
\hline $\begin{array}{c}\text { Загальні адміністративні } \\
\text { витрати }\end{array}$ & 39356 & 44202 & 53670 & 62936 & 69302 \\
\hline Інші витрати & 3089 & 15116 & 2011 & 2379 & 2683 \\
\hline Відрахування в резерви & 198310 & 49206 & 23758 & 10714 & 29878 \\
\hline Податок на прибуток & -418 & 3681 & 5057 & 4769 & 3538 \\
\hline $\begin{array}{c}\text { Чистий прибуток } \\
\text { (збиток) }\end{array}$ & -159388 & -26491 & 22339 & 58356 & 41296 \\
\hline
\end{tabular}

*Без урахування неплатоспроможних банків. За даними: [278]

Основною причиною погіршення фінансового результату у 2020 році стало формування резервів під очікувані збитки „Витрати на резерви за кредитами у 2020 році зросли на 91\% до 20.8 млрд грн проти 10.9 млрд грн у 2019 році через визнання низки банків щодо погіршення якості активів через фінансові труднощі позичальникіів.[279]

Вагомим для подальшого розвитку банківської системи України є чіткий та налагоджений механізм ризик менеджменту банків.

Банківський ризик слід розглядати як ймовірність недоотримання доходів або зменшення ринкової вартості капіталу банку внаслідок несприятливого впливу зовнішніх чи внутрішніх чинників, стану корпоративного управління, а також потенційну можливість отримати додатковий прибуток у разі реалізації певних, прийнятних для банку, фінансових ризиків.[287] 
Для діяльності банківських установ характерними $є$ наступні ризики: кредитний ризик, ризик ліквідності, ризик зміни процентної ставки, ринковий ризик, валютний ризик, операційно-технологічний ризик, ризик репутації, юридичний ризик, стратегічний ризик . Банківська установа, проводячи різноманітні операції, свідомо бере на себе всі відповідні ризики.

Після змін, що відбулися в банківській системі останніми роками ,менеджерам довелося змінити підхід до ризик менеджменту банку, закрема до методик вимірювання ризику, стрес-тестування та корективів планів на випадок непередбачених обставин. Прозорість у роботі банків дає можливість більш чітко сформувати вимоги контролюючих органів щодо управління ризиками.

3 метою підвищення якості управління кредитним ризиком НБУ запровадив вимоги щодо контролю за оцінкою майна, що отримується в заставу за наданими кредитами. Зокрема передбачається здійснення верифікації вартості майна; ротації оцінювачів майна; моніторингу незалежності процесу відбору зовнішнього оцінювача; бек-тестування вартості майна (аналізу зіставності вартості продажу майна з його вартістю, визначеною під час останньої оцінки)

3 урахуванням результатів аналізу практичного впровадження банками та банківськими групами вимог про організацію системи управління ризиками, яке завершилось у поточному році, а також у тісній співпраці з банківською спільнотою Національний банк у змінах до зазначеного положення: передбачив право відповідальної особи банківської групи організовувати систему управління ризиками без урахування учасників банківської групи, які не мають суттєвого впливу на діяльність банків-учасників банківської групи, що сприятиме забезпеченню співставності величини ризиків та витрат на управління ними; уточнив визначення посад головного ризик-менеджера та головного комплаєнс-менеджера, що враховує різну організаційну структуру банків; спростив процедуру автоматичного ухвалення кредитних рішень для стандартизованих кредитних продуктів, що сприятиме оперативності прийняття кредитних рішень; збільшив періодичність звітування про операційний ризик перед правлінням банку та періодичність проведення стрес-тестування 
операційного ризику, що зменшить навантаження на банки під час підготовки ними управлінської звітності. [284]

У кожному банку необхідним є розробка індивідуальних програм щодо управління ризиками відповідно до складу клієнтської бази та банківських операцій відповідно до наступних принципів: рівні ризиків постійно змінюються відповідно до зовнішніх чи внутрішніх умов; ризики банків безпосередньо пов’язані з ризиками їх клієнтів; всі ризики є взаємопов'язаними.

Процес управління ризиками для банківських установ передбачає наступні етапи: визначення причин виникнення ризиків; оцінка величини ризиків; вибір методів управління ризиками для їх мінімізації; здійснення безперервного контролю за рівнем ризиків.

При управлінні ризиками банк повинен оцінити, які ризики і в якій мірі може прийняти на себе банк та проаналізувати їх на якісному та кількісному рівні.

Для ефективної діяльності банків України в сучасних умовах все більшу роль відіграють банківські асоціації, що приймають активну участь в координації діяльності комерційних банків, а також в розробці та аналізі банківського законодавства. Для підвищення ефективності роботи банківським установам необхідно постійно співпрацювати між собою, тому для захисту своїх інтересів банкам важливо об'єднуватися.

В сучасних умовах, значну увагу банкам необхідно приділяти розробленню та постійному оновленню веб-сайтів, що забезпечують надання інформації про банк та конкретні його послуги та продукти, рекламу, можливість здійснювати банківські операції клієнтами цілодобово не відходячи від комп'ютера та підтримку клієнтів. Правильно розроблений веб-сайт банку сприяє збільшенню клієнтів банку та ефективному здійсненню їх обслуговування. Головною умовою при цьому $\epsilon$ представлення банківських продуктів 3 якомога більшою зрозумілістю для клієнтів. Для цього банки застосовують різні нововведення, наприклад представляють на сайтах відое-помічники щодо надання своїх послуг у вигляді цікавих роз’яснювальних відеоролеків. 
Реалізація заходів щодо підвищення конкурентоспроможності банківських послуг комерційного банку повинна супроводжуватись коригуванням кадрової політики і орієнтації іiї на безперервність інноваційної діяльності.

Кадрова політика комерційного банку повинна включати в себе: створення умов для ефективної роботи, навчання персоналу, систему мотивації, вдосконалення та зміцнення корпоративної культури, формування колективу високопрофесійних фахівців.

Банки також здійснюють постійний контроль за роботою працівників через дослідження задоволення клієнтів методами телефонного опитування анкетування на сайтах, а також через анонімних клієнтів, що дозволяє перевірити результати роботи персоналу.

Важливими факторами в якості обслуговування клієнтів є також кількість відділень банку та зручність їх графіка роботи для клієнтів, зокрема, продовженість робочого дня, робота у вихідні дні, без перерви на обід. . Для банків дані фактори вимагають значних витрат, але в майбутньому це призводить до збільшення кількості клієнтів та підвищення рівня їх задоволеності.

Якість обслуговування в банку залежить від доступної для клієнтів системи звернень. Банки, що зацікавлені в довготривалих відносинах з клієнтами та в партнерських відносини з ними, мають створити зручну систему звернутися до керівництва банку з приводу будь-якого питання щодо діяльності банківської установи. Для цього комерційними банками можуть застосовуватись різні прийоми, зокрема безкоштовні цілодобові контактні номер телефонів.

Банківські асоціації - добровільні об'єднання банків, створене як неприбуткова організація з метою захисту та представлення інтересів своїх членів, координації роботи у сфері спільних інтересів, співпраці з органами влади у правовій сфері, розвитку міжрегіональних та міжнародних зв'язків, забезпечення наукового та інформаційного обміну і професійних інтересів, розробки рекомендацій щодо банківської діяльності.

Слід зазначити, що НБУ постійно взаємодіє із банківськими асоціаціями через консультування при прийнятті важливих рішень в банківському 
законодавстві, надає необхідні роз'яснення, розглядає пропозиції щодо питань регулювання банківської діяльності. В Україні зареєстровані і працюють наступні загальнонаціональні банківські асоціації: Асоціація українських банків (АУБ), Український кредитно-банківський союз (УКБС), Незалежна асоціація банків України (НАБУ), Українська міжбанківська асоціація членів платіжних систем "СМА", Асоціація «Українська спілка учасників платіжного ринку», Асоціація "Українська національна група членів та користувачів СВІФТ" (УкрСВІФТ).

Основними принципами створення банківських асоціацій повині бути: встановлення небхіних принципів належності до асоціації, визнання асоціації державними ораними влади, розробка правил взаємодії безпосередньо членами асоціації, встановлення чіткого контролю за виконанням правил асоціації та визначення санкцій за їх порушення.[274, С.335]

Всі банківські асоціації $є$ самоврядними громадськими неприбутковими організаціями і покривають свої операційні витрати за рахунок членських внесків. В Україні більшість банків є членами трьох основних універсальних асоціацій: АУБ, УКБС та НАБУ.

Роль банківських асоціацій для розвитку банківської системи України є значною, адже вони виявляють загальні проблеми діяльності комерційних банків та захищають їх інтереси на державному рівні. Банківські асоціації виконують вкрай важливу роль при розробці банківського законодавства а також його удосконалення та підвищенні престижу банківської діяльності.

Таким чином, на даному етапі українська банківська система розвивається, поступово долаючи кризові наслідки. Аналіз діяльності основних банківських показників засвідчив, що банківська система України подолала кризовий стан і в цілому стабілізувала свою роботу, хоча банки-поки що не в повній мірі виконують функцію ефективних фінансових посередників у частині кредитування розвитку вітчизняної економіки. Щодо простроченої заборгованості за кредитами, то банки повинні інтенсивніше розчищати баланси, при цьому непрацюючі кредити слід реструктурувати, продавати чи списувати. 
Для банківських установ в сучасних умовах необхідним є удосконалення правової бази регулювання банківської діяльності, а також більш фундаментальна оцінка їх діяльності на перспективу для прийняття швидких та ефективних рішень.

Для успішного розвитку банкам в сучасних умовах необхідним $є$ розробка заходів спрямованих на підвищення якості обслуговування клієнтів, а також модернізацію та оптимізацію банківських операцій та послуг. При цьому банкам слід звернути увагу на диверсифікацію банківських активів; впровадження нових депозитних програм; виконання та дотримання нормативів НБУ, що регулюють діяльність комерційних банків; та реалізацію нових продуктів, що не створюватимуть суттєвих ризиків.

Банкам необхідно приділяти значну увагу до пошуку шляхів щодо удосконалення напрямів управління ризиками, що сприятиме вчасному їх виявленню, оцінці та контролю. Важливим є розробка комплексної системи ризик-менеджменту банку та створення окремих банківських відділів чи комітетів 3 управління ризиками із залученням висококваліфікованих спеціалістів, що зможуть не лише оцінювати ризики, а й впроваджувати незалежну, інтегровану систему управління ними.

Реалізація даних заходів в майбутньому дозволить мінімізувати вплив негативних факторів на банківську діяльність у короткостроковій перспективі та створить умови для прискореного розвитку банківської системи України.

Роль банківських асоціацій для розвитку банківської системи України є значною, адже вони виявляють загальні проблеми діяльності комерційних банків та захищають їх інтереси на державному рівні. Банківські асоціації виконують вкрай важливу роль при розробці банківського законодавства а також його удосконалення та підвищенні престижу банківської діяльності.

Швидкість реакції банку в створенні нових технологічних продуктів $є$ важливим для обслуговування максимальної кількості клієнтів. Саме тому вітчизняним банкам доцільно постійно розвивати нові та удосконалювати традиційні канали збуту своїх продуктів та послуг 3 використанням 
високотехнологічних систем. При здійсненні операцій щодо залучення та розміщення грошових коштів банкам слід розробляти інноваційні продукти та залучати клієнтів можливістю отримання певного набору додаткових послуг та програм лояльності.

Значну увагу необхідно приділяти кадровій політиці банку шляхом запровадження мотивацій та постійного контролю за роботою персоналу. Запроваджувати більші можливості безпосереднього спілкування з клієнтами щодо здійснених операцій та консультаційних послуг.

Також слід розробити відповідні процедури контролю для кожної складової якості окремо 3 метою швидкого реагування і зміни тактики конкурентної боротьби, що в майбутньому сприятиме зростанню іміджу банку. 